\title{
Stress and Its Brunt on Employee's Work-Life Balance (Wlb): A Conceptual Study
}

\author{
Ritu Atheya*, Dr. Renu Arora** \\ *Assistant Professor, Institute of Home Economics (Delhi University) \\ ** Associate Professor, Institute of Home Economics (Delhi University)
}

\begin{abstract}
In a society filled with conflicting responsibilities and commitments, work-life balance has become a predominant issue at the workplace. Changes in the social, political and economic fabric of societies have influenced and continue to influence both the nature of employment and its relationship to life outside work. The concept of Work-life balance is becoming more and more relevant in an ever dynamic working environment. The effect of increased working hours is having a serious implication on the lifestyle of huge number of people, which ultimately affects their social and psychological well being. Stressful job conditions and long working hours are the major predictors of work-life conflict.

Work-life balance $(W L B)$ is an important area of human resource management that is receiving increased attention from government, researchers, professionals etc. Human resource professionals are seeking innovative ways to positively impact the bottom line of their companies, improve employee morale, retain employees with valuable company knowledge, and keep pace with workplace trends by providing work-life initiatives. This paper focuses on the impact of stress on the lives of employees, identifies the determinants to employees' work-life balance and also suggests the roles and responsibilities of key parties by providing suitable ways to employers for facilitating a better WLB options at the work-place.
\end{abstract}

Keywords: Employee, Stress, Work, Work-Life Balance and Pressure

\section{Introduction}

"No one can have everything and do everything at the same time". Psychologist - Oprah Winfrey

At present, work environment has become more stressful because of diverse role expectations, cut throat competition, globalization and technological innovations. Such changes have created several complications on both the domestic and professional fronts of the employees. The pressure of work has been intensifying and there is growing feeling among employees that the demands of work begin to dominate life and sense of work-life balance is felt. The challenge of integrating work and family life is a part of everyday reality for the majority of employees now-a-days.

"Work-life balance is a state of equilibrium in which the demands of both a person's job and personal life are equal" (Lockwood, 2003). It is the ability to effectively manage the juggling act between paid work and the other activities, that are important to people.

As Kodz et al., (2002) explained, the principle of work-life balance is that "there should be balance between an individual's work and his life outside work and this balance should be healthy". Further in 2003, Work Foundation defined the concept of work-life balance and highlighted that it is all about employees achieving a satisfactory equilibrium between work and non-work activities (i.e, parental responsibilities and wider caring duties, as well as other activities \& interests).

Changes in the social, political and economic fabric of societies have influenced and continue to influence both the nature of employment and its relationship to life outside work. The concept of Work-life balance is becoming more and more relevant in an ever dynamic working environment.

WLB, from employee perspective, is the maintenance of responsibilities at work and at home. Employees view the benefits or working conditions as work-life benefits in which they help employees to balance the families and work domains (Bardoel, Tharenou, \& Moss, 1998; Russell \& Bowman, 2000). In contrast, work-life conflict is a demand in a form of inner role conflict, in which role pressures from the work and other life domains, such as family, are mutually incompatible in some respect, whereby participation in one role is made more difficult by the virtue of participation in the other (Greenhaus \& Beutell, 1985). Initially, the concept of work-life conflict was focused on impact of family demands on work. It now extends to the impact; work has on individual stress, relationship and family well being (Russell \& Bowman, 2000).

Today, the new age workforce comprises mostly of knowledge workers, who are techno-savvy, aware of market realities, are materially focused and have a higher propensity to switch jobs (Edris, 2004).The increasing emphasis on knowledge-based competitiveness in the current turbulent environment also accelerated the importance of human capital (Wan, Kok \& Ong , 2002). Under a knowledge-based economy, the attraction 
and retention of a potential workforce is fast becoming a challenge to many employers (Work life solutions, 2010).

For this reason, WLB has emerged as a strategic issue for HRM and a key element of organization's employee retention strategies. Achieving a balance between work and personal life and responding to the needs and expectation of an employee, plays a crucial role in the employee retention. Companies can reach out to the employees by introducing raft of initiatives such as work from home, part-time working, telecommuting etc. Companies can put in place the work structures that can create these opportunities and create a very balanced professional-personal life for their employees.

\section{Review Of Literature}

We live in stressful times, and each of us deals with stress every day. Scientists agree that moderate amount of stress can be benign, even beneficial, and most people are equipped to deal with it. However, increasing levels of stress can rapidly lead to low employee morale, poor productivity, and decreasing job satisfaction (Stranks, 2005). Some of the specific symptoms that relate directly to productivity in the work environment are abuse of sick time, cheating, chronic absenteeism, distrust, organisational sabotage, tardiness, task avoidance, and violence in the workplace. Other serious repercussions are depression, alcohol and drug abuse, marital and financial problems, compulsive eating disorders, and employee burnout.

Stress in the workplace had emerged as a major issue for businesses and it has reached alarming proportions. According to the National Institute for Occupational Safety and Health, 80 percent of workers experienced job stress (Despande, 2012).

Steven L. Sauter, chief of the Applied Psychology and Ergonomics Branch of the National Institute for Occupational Safety and Health in Cincinnati, Ohio, stated that recent studies showed that "the workplace has become the single greatest source of stress" (The CQ Researcher Online, 2013).

According to Coleman (1976), modern age has been called the 'age of anxiety and stress'. Studies have projected that the stress results in a wider range of somatic and psychological patterns which is detrimental to the individual too (Cooper and Cartwright, 1994; and Edworthy, 2000).

Work-related stress can affect individuals when they feel an inability to cope or control demands placed within their work environment and can eventually contribute to the development of maladaptive behaviors such as drinking and smoking (Stansfield et al., 2000) and physical conditions such as depression, anxiety, nervousness, fatigue and heart disorders (European agency for Safety and Health at work, 2002).

Lluminari Landmark Study (2004) found that people who worked under stressful conditions, which can include work-life conflicts or lack of social support, autonomy and control, were at least twice as likely to experience the mentioned physical and mental effects - heart and cardiovascular problems, anxiety, depression and demoralization, certain cancers, infectious diseases, conflicts injuries and back pain etc. as compared to other workers.

A research conducted by Ezzedeen and Swiercz (2002) explained that the "modern work has become knowledge based, fluid, and intellectual; overworked people think about work all of the time. For many people, work has become cognitively intrusive." It was revealed that employees were often preoccupied with work when not working, and when in the company of family and loved ones, experienced an inability to be meaningfully engaged in non-work spheres.

As conceptualized earlier, work and family life are separate domains having no bearing on each other however, it is now recognized that domestic identities and responsibilities sometimes spill over into the workplace and organizational identities and responsibilities often cross into home life (Halford, 1997; Kanter, 1977). Whereas personal or family lives, interfere with work are associated for fewer hours as compared to the work that interferes with life matters (Reynolds, 2005). However, employees' attitudes towards their hours of work, and perceptions and complaints about work-life imbalances actually deals with working time and complaints about time pressure which are unrelated to hours, actually worked (Roberts, 2007).

Researchers, Buddeberg-Fischer et al. (2008) stressed that a well balanced integration of professional and private life is an essential goal for the new generation. Moreover, informal arrangements and managerial discretion are important in realizing work and care balance (Burgess et al., 2007).

Work-life balance and stress go hand in hand. What seems to matter in this regard is the importance workers place on balance in their lives and the effectiveness of workplace policies and practices in supporting them to achieve this goal.

(Ross \& Vasantha, 2014).

\section{Objectives}

1. To identify the determinants of Employees’ Work- Life Balance.

2. To suggest the roles and responsibilities of key parties for maintaining WLB at workplace.

3. To recommend various ways to employers for overcoming work stress. 


\section{Determinants of Work-life Balance}

The determinants of work-life balance are located in the work and home contexts. At work, the demands of work may be either too low or too high; and may support balance through policies and practices designed to facilitate balance, such as occasional time off and flexible hours, or may strictly limit these. Alternatively, it may demand and expect long and irregular hours and be intolerant of taking time off to deal with family emergencies. The demands of home refer to the commitments and obligations outside work. These may be individual factors or it may exist in the family, in the community or through choice of leisure activities. Following determinants have been identified which impact the issue of employees' work life balance.

\section{Organizational Factors}

- Present annual income of employee

- Tenure in the present organization

- Department in which an employee is working

- Type of organization

- Nature of Job

- No. of years of previous experience

- Level of hierarchy in the organization

- Term of Contract

- Situational factors (like unreasonable \& conflicting demands etc.)

- Unclear responsibilities and expectations

- Support from employer and management

- Support from colleagues

- Policies of organization

- Technology and its use

- Long Working Hours

- Excessive workload etc.

\section{Individual Factors}

- Age of an employee / Life Stage of Employee.

- Marital Status

- No. of Members of family

- Type of Family / Family Structure

- No. and Age of the kids

- No. of Dependents

- Educational Qualification

- Mobility from native place

- Attitude and values of employee

- Psychological factors

- Support from family members

- Energy Levels of employee

- Self High Expectations

Juggling competing demands is tiring, if not stressful, brings lower productivity, sickness and absenteeism, so work-life balance is an issue for all employees and all organisations.

(Swift, 2002).

\section{Roles and responsibilities of key parties in work-life balance}

The key parties or actors in the Work-life Balance are:

1. Individuals

2. HR Manager

3. Senior Manager

4. Line Manager

5. Union

\section{Individual}

- Makes choices carefully about fit with organization when applying for a job. 
- Identifies personal needs ('must haves' versus 'like to haves') and possible solutions (being realistic about what is possible).

- Takes responsibility for delivering their own workload as agreed with their manager.

- Reviews and modifies arrangements as the personal circumstances changes.

- Is supportive of colleagues and managers Work-life balance needs.

- Participates in development of organizational Work-life balance strategy

\section{HR manager}

- Develops a Work-life balance strategy that meets the needs of both employees and the organization

- Ensures work-life balance is embedded in all HR policies (including provision of induction and training).

- Supports individual managers to improve Work-life balance in the organization and find solutions to employees Work-life balance needs.

- Ensures training on Work-life balance principles and practice is provided to managers.

- Provides assurance to management that the Work-life balance strategy is being appropriately implemented in the organization.

\section{Senior manager}

- Sets the environment that will make Work-life balance work.

- Walks the talk/leads by example, by modeling Work-life balance in his/her personal life.

- Sets Work-life balance performance expectations for managers, so that they find solutions to employees Work-life balance issues.

- Leads the development of the Work-life balance strategy

Line manager

- Explicitly communicates support for Work-life balance initiatives.

- Walks the talk/leads by example.

- Implements organizational Work-life balance strategy.

- Works with individual employees to manage Work-life balance fairly and creatively and to find individual solutions (by challenging existing practices, identifying scope for flexibility, identifying opportunities as well as limitations).

Union

- Promotes Work-life balance to members and employers.

- Articulates the collective interests of members in Work-life balance issues.

- Works in partnership with employer to develop a Work-life balance strategy and to improve Work-life balance in the organization.

- Leads members' participation in developing Work-life balance solutions.

- When required, assists individuals to negotiate Work-life balance solutions.

\section{Suggestions to Overcome Stress and To Have a Balanced Work life}

A number of recommendations, based on current thinking and empirical literature may assist readers to work towards making work-life balance both a strategic goal and a reality in their organizations.

- Rather than classifying the workweek as five days long, allow employees to work four 10-hour shifts. This schedule enables employees to have three days off each week instead of the typical two-day weekend.

- When possible, incorporate a work-from-home policy. Offering this benefit even a few days per year can make a difference.

- Make day care available to staff on-site or incorporate a benefit which would provide day care at a discounted rate.

- Offer a tax preparation service benefit.

- Offer free gift-wrapping services during the holidays and for special occasions.

- Consider high-performers and present family vacation packages in addition to, or in place of, monetary bonuses.

- Offer concierge services to help employees balance the many errands in life. 
- Offer scheduling of flexitime, where employees can provide their input on their preferred work schedule ( 7 a.m. to 4 p.m., 8 a.m. to 5 p.m., 9 a.m. to 6 p.m.). If multiple employees request the same shift, offer a rotating schedule to satisfy everyone.

- Offer seasonal hours, where employees can leave early on Fridays during certain seasons.

- Make yearly anniversaries with the company an extra paid time off day to encourage employees to celebrate their tenure. This day off will also serve as a reminder that their employer cares.

- Encourage employees to avoid checking their work e-mail and voice mail after the workday and on weekends, to separate work from their personal lives.

- Allow employees to take a longer lunch, if they come in early or work later, to make up the missed time. This option will make it easier for staff to schedule appointments or run errands on their break.

- Hold virtual meetings, so employees do not have to be on-site to attend.

- Encourage employees to take frequent breaks to rehydrate and go to the restroom (at least once every two hours). This may seem unnecessary to address, but many busy people forget to take time out of the day for their personal well being.

While you may not be able to initiate all of these suggestions, even tackling a few will help employees see your organization's concern for true work-life balance in the workplace. Address these recommendations with your leadership team as soon as possible to tailor your approach and set your plan into action.

\section{What are three simple things one can do to achieve work-life balance?}

Just remember A-C-E, "ace": Awareness, Choice and Energy.

This 3 step process is simple, does not cost any money and doesn't take any more time out of busy day. Its power lies in its simplicity.

A. Deepen your awareness through listening deeply and noticing two things: what throws you off balance, and what brings you calm and fulfilment.

AWARENESS- Being mindful, present in your life.

B. Exercise the power of choice. Choose to release what drains you and embrace what truly nourishes you. When you begin to make life giving choices in your life, you will be able to make many more decisions easily. Realizing your life is the consequences of your choices becomes very empowering.

C. Reclaim the energy that is natural birthright. Your life will become a powerful dynamic concentric circle. The more aware you become, the more you become aware of your choices. The more you realize that your life is created by your choices, the more real energy and power you will experience in your life.

\section{Conclusion}

Job stress in any organisation has been increasing over the last few decades and has important implications for performances. Despite its importance, there has been a lack of proper stress management programs. As stress affects the outcome of productivity, monitoring and managing job stress is extremely important. It is primarily the responsibility of an individual to balance work and life and initiate steps to reduce stress and burnout. The organization can indeed facilitate the process. The individual has to explore his values, aspirations, and goals to understand what he expects from work and life and then develop the suitable ways of balancing work and life. Hence, he has to introspect on his job contents, ways of coping and relationship management. On the other hand, organization can initiate cutting edge work-life balance practices to help the employees' mange their affairs more effectively. It can also train employees to understand the issues of worklife and stress management assistance programmes. Even with the availability of employee assistance programs in organisation such as stress management and flexible work arrangements, the complex nature of stress still seems to influence the health and work-life balance negatively. So it is the responsibility of the employer and employee to contribute to the better work-life balance for fruitful productivity.

\section{References}

[1] Bardeol, E., P. Tharenou \& S. Moss. (1998). Organizational predictors of Work-Family practices. Asia Pacific Journal of Human Resources, 36(3), 31-49.

[2] Buddeberg-Fischer, B., Stamm, M., \& Klaghofer, R. (2008). The new generation of family physicians- career motivation, life goals and work-life balance. Swiss Med Wkly.2008:138(21-22):305-312, URL: http://www.smw.ch., Accessed: 2/1/2014.

[3] Coleman, J.C. (1976). Abnormal Psychology and Modern Life (Indian Reprint). Bombay: Taraporewalla Press.

[4] Cooper, C. L. \& Cartwright, S. (1994). Healthy Mind, Healthy Organization: A Proactive Approach to Occupational Stress. Human Relations, 47(4), 455-471.

[5] Deshpande R.C. (2012). A healthy way to handle work place stress through yoga, meditation and soothing humor. International Journal of Environmental Sciences. 2(4). Edworthy, A. (2000). Managing Stress. Buckingham: Open University Press.

[6] Ezzedeen, S.R., \& Swiercz, P.M. (2002). Rethinking work-life balance: Development and validation of the cognitive intrusion of work scale (CIWS) - A dissertation research proposal. Proceedings of the 2002 Eastern Academy of Management Meeting. 
[7] Greenhaus, J.H. \& Beutell, N. (1985). The impact of human resource management practices on turnover, productivity, and corporate financial performance. Academy of Management Journal 38(3), 635-672.

[8] Jayashree R. (2010). Stress Management with Special Reference to Public Sector Bank Employees in Chennai. International Journal of Enterprise and Innovation Management studies, 1(3), July-December.

[9] Kanter, R. M. (1977). Work and family in the United States: A critical review and agenda for research and policy. New York: Russell Sage Foundation.

[10] Kodz, J., Hraper, H., Dench, S. (2002). Work-life Balance: Beyond the Rhetoric. The Institute of Employment Studies, Report 384, Brighton.

[11] Lockwood, N.R. (2003). Work/life Balance: Challenges and Solutions. SHRM Journal, 48(6), 81-90.

[12] Lluminari Landmark Study (2004). Creating Healthy Corporate Cultures for Both Genders: A National Employee Survey. Lluminari, Inc, June.

[13] Reynolds, J. (2005). In the Face of Conflict: Work-Life Conflict and Desired Work Hour Adjustments. Journal of Marriage and Family, 67(5), 1313-1331, National Council on Family Relations. URL: http://www.jstor.org/stable/3600315, Accessed: $10 / 11 / 2013$.

[14] Roberts, K. (2007). Work-life balance - the sources of the contemporary problem and the probable outcomes: a review and interpretation of the evidence. Employee Relations, 29(4), 334-351. Emerald Group Publishing Limited.

[15] Ross, S.D. \& Vasantha, S. (2014). A Conceptual Study on Impact of Stress on Work-Life Balance. Sai Om Journal of Commerce \& Management, 1(2), February, 1.

[16] Russell, G. \& L. Bowman. (2000). Work and family, Current thinking, research and practice. Prepared for the Department of Family and Community services as a background paper for the National Families Strategy.

[17] Singh, P., \& Khanna, P. (2011). Work-Life Balance: A Tool for Increased Employee Productivity and Retention. Lachoo Management Journal, 2(2), July - December 2011.

[18] Stranks, J. (2005). Stress at work: Management and prevention. Oxford: Elsevier.

[19] Swift, L. (2002). Work-life balance important in relief world, too. Reuters Alert Net URL: http://www.alertnet.org/thefacts/reliefsources. Accessed: 27/12/2013.

[20] Wan, D., Kok, V., \& Ong, C. (2002). Strategic Human Resource Management and Organizational Performance in Singapore.

[21] URL: http://www.greatworksolutions.com/work-life-balance.html (1 of 2). Accessed: 7/2/2013.

[22] Work life Solutions (2010). What is Work-Life Balance? URL: http://www.greatworksolutions.com/work-life-balance.html. Accessed: 7/7/2011 